\title{
被覆形鋼管コンクリート柱材における鋼管の幅厚比・径厚比の制限值 LIMITING WIDTH (DIAMETER)-THICKNESS RATIO OF TUBES OF COMPOSITE STEEL TUBE AND CONCRETE COLUMNS WITH ENCASED TYPE SECTION
}

\author{
松井千秋*1, 津田惠吾*2, 森 武史*3 \\ Chiaki MATSUI, Keigo TSUDA and Takeshi MORI
}

\begin{abstract}
In AIJ design formula for composite steel tube and concrete structures, the limiting width (diameter) -tothickness ratio of steel tube is relieved to 1.5 times that for a hollow tube. In this paper, it is investigated whether the limiting value for concrete-encased type section is appropriate or not.

As the experimental parameters, shape of steel tube, section type and width (diameter) -to-thickness ratio are selected. Total thirty-four stub column specimens are tested under concentric load. From the view point of the maximum strength, current limiting width (diameter)-to-thickness ratio is practically appropriate.
\end{abstract}

Keywords : stub column test, maximum strength, local buckling, encased type, filled type 短柱圧縮試験, 最大耐力, 局部座屈, 被覆形, 充填形

1. 序

鋼管コンクリート柱の断面形状として鉄骨鉄筋コンクリート構造 計算規準・同解説 ${ }^{1)}$ (以下 SRC 規準と略す) には, 被覆形・充填形・ 充填被覆形の 3 形式（表-1）が示されている.これらの断面の鋼管 の幅厚比·径厚比の制限値は裸鉄骨の場合の值の1.5倍に緩和されて いる1)(現行の SRC 規準以前には，円形鋼管のみを対象とした文献 $2 て ゙ は$ 径厚比は 160 以下と規定され，角形鋼管も取り入れられた文献 3 では，鍓構造設計規準4)による事となっていた).

3つの断面形式のうち角形鋼管を用いた充填形については, 幅厚 比の制限值を裸鉄骨の場合の制限値を 1.5 倍䋸和してもコンファイン ド効果によって耐力と変形能力が確保できることが明らかとなって (る5), 6). 充填被覆形については，充填形と同じ幅厚比・径厚比制 限値を規定しておけば問題はないと考えられる。

しかしながら, 被覆形については, 文献 7) -11) で種々の荷重条 件の下で実験的研究が行われているが, 幅厚比・径厚比を変化させ た研究例はなく, 耐力と変形能力におよほす幅厚比・径厚比の影響 は明らかになっていない：鋼管の局部座屈については，文献 11)が 径厚比21の円形鋼管を用いた被覆形の試験体では局部座屈が観察さ れなかったこと,幅厚比が23の角形鋼管を用いた被覆形ではフラン ジが内側に凸の形となる局部座屈を生じていたことを報告している
だけであり, 幅厚比・径厚比の制限値は, 現在の規定値で良いのか どうか不明である.

以上のことから本研究の目的は, 被覆形の鋼管コンクリート柱材 の鋼管の幅厚比・径厚比の制限值が, 現在規定されている值で適切 であるのかどうかを, 中空形, 充填形, 充填被覆形も含めて短柱圧 縮試験を行い,その最大耐力と変形挙動を調べることにより検討す ることである.

2. 実験

2. 1 実験計画

研究目的に合致するよう，以下に示すように実験変数を選んだ.

1）鋼管断面：角形鋼管, 円形鋼管

2）断面形式：中空形, 充填形, 被覆形, 充填被覆形

3）幅厚比: $25,33,47,65,94$ 径厚比 : $37,52,72,103,138$

4）带筋比: $1.0 \%, 0.5 \%$

以上を実験変数とし, 計 34 体の実験を計画した。 以下に，実験变数の值の設定に関して説明する。

1）鋼管断面については, 鋼管コンクリート柱として一般に使われて いる正方形角形鋼管および円形鋼管を対象とする.
*1 九州大学工学部建築学科 教授. 工博

*2 九州大学工学部建築学科 助手. 志博

*3 戸田建設(当時九州大学 4 年生)
Prof., Dept. of Architecture, Kyushu Univ., Dr. Eng.

Research Assistant, Dept. of Architecture, Kyushu Univ., Dr. Eng.

Toda Corporation 


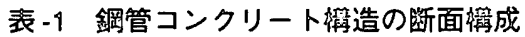

\begin{tabular}{|c|c|c|c|}
\hline & 被征形 & 充填形 & 充填被蕧形 \\
\hline $\begin{array}{l}\text { 笛 } \\
\text { 毙 } \\
\text { 龬 } \\
\text { 管 }\end{array}$ & & &  \\
\hline $\begin{array}{l}\text { 円 } \\
\text { 形 } \\
\text { 鋼 } \\
\text { 管 }\end{array}$ & & & ? \\
\hline
\end{tabular}

2）断面形式については, 銅管のみの中空形, コンクリートを全充填 した充填形，龬管に被覆コンクリートを施した被覆形，およびコ ンクリートを全充填し, 被覆コンクリートを施した充填被覆形を 対象とする．充填被覆形については，4種類の断面形式における 挙動の違いを検討するために設定するので，裸鉄骨における幅厚 比・径厚比制限值に近い幅厚比 47 ・径厚比 72 のそれぞれ 1 体ずつ とした.

3）幅厚比・径厚比については, 裸鉄骨で規定されている幅厚比・径 厚比制限值内のものから銅管コンクリート構造柱材の幅厚比・径 厚比制限值を超えるものまでの広範囲な部分をカバーするように, 幅厚比を 25〜94, 径厚比を 37〜138に設定した。

4）帯筋比 ${ }_{w} p={ }_{w} \mathrm{a} /\left(b^{\prime} \mathrm{x}\right)$ (ここに ${ }_{\mathrm{w}}$ ：帯筋比 (\%), wa：一組の带筋の断面 積 $\left(\mathrm{cm}^{2}\right), \mathrm{b}^{\prime}$ : 鉄骨フランジ位置でのコンクリート有効幅 $(\mathrm{cm}), \mathrm{x}$ ：帯筋 の間隔 $(\mathrm{cm})$ ) については，龬管コンクリート構造設計例より一般 的であると思われる1.0\%を設定した.帯筋比の違いが耐力および


た. 帯筋比 $0.5 \%$ $\%$ のは, 鋼管コンクリート構造柱材の幅厚比・ 径厚比の制限值に近い幅厚比 65, 径厚比 103 のそれぞれ 1 体ずつ とした.

以上の実験変数のもとで，短柱圧縮試験を行った。

表-2に試験体一覧を示す，試験体の名前は実験条件を示し，最初 の英字で銅管の断面形 ( $\mathrm{R}$ ：角形, $\mathrm{C}$ ：円形) を, 次の数字で幅厚比・ 径厚比を, 次の英字で断面形 ( $\mathrm{V}$ : 中空形, $\mathrm{F}$ : 充填形, $\mathrm{E}$ : 被璀形, FE：充填被覆形）を示している。最後に英字のAが付いているもの

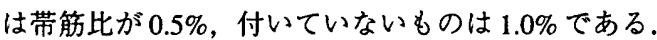

\section{2 試験体}

a）断面 試験体の断面は，角形鋼管は $150 \times 150 \mathrm{~mm}$ ，円形龬管は $165.2 \phi$, 被覆コンクリートは 250x250mmである. 材長は角形鋼管 が $450 \mathrm{~mm}$ ，円形䥤管が $495.6 \mathrm{~mm}$ で銅管幅・径の 3 倍である.

被覆形における銅管および主筋の配置については,実際に使われて いる範囲にあると考えられる鋼管のかぶりを角形銅管, 円形龬管それ ぞれ，全せいの 0.2 倍， 0.17 倍とし，主筋のかぶりは 0.11 倍とした.

b）銅管 実験に用いた鋼材は, 板厚 $6.0 \mathrm{~mm}, 4.5 \mathrm{~mm}$ の角形鋼管は市 販の冷間成形角形銅管 (STKR400, 公称断面はそれぞれ $150 \times 6.0$ と $150 \times 4.5)$, 板厚 $4.5 \mathrm{~mm}$ の円形銅管は市販の冷間成形円形鈿管 (STK 400 ，公称断面は $165.2 \phi \times 4.5)$ である. 板厚 $3.2 \mathrm{~mm}, 2.3 \mathrm{~mm}$, $1.6 \mathrm{~mm}, 1.2 \mathrm{~mm}$ の鋼管は, SS 400 相当の銅板より製作した。角形龬 管（板厚 $3.2 \mathrm{~mm}, 2.3 \mathrm{~mm}, 1.6 \mathrm{~mm}$ ）は，鋼板より满形鐝を製作し，一 対の满形龬を溶接することにより製作した（角部の曲率半径は厚さ
表-2 試験体一筧

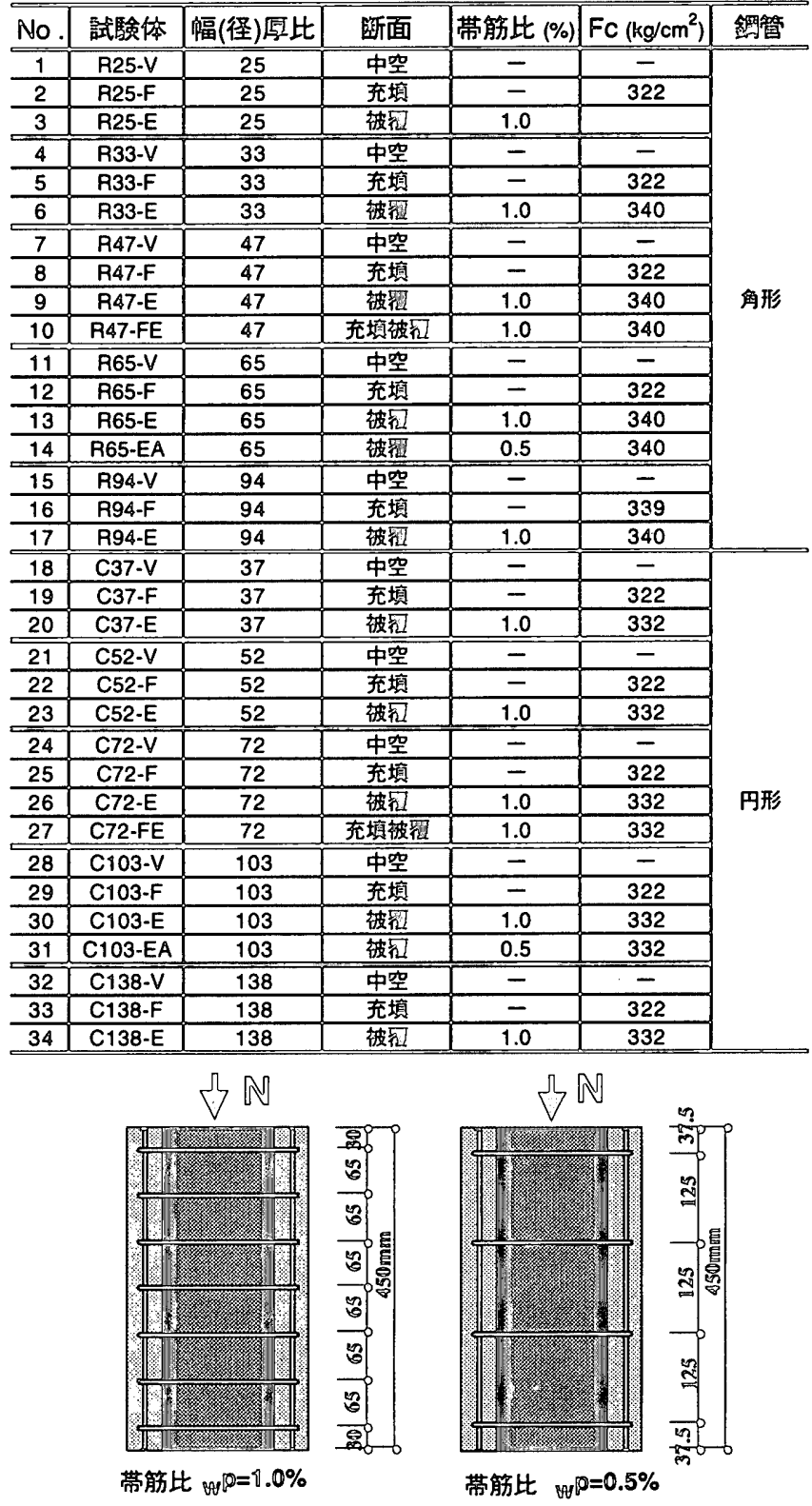

（角形鋼管を用いた被㠅形の場合）



（角形鋼管）

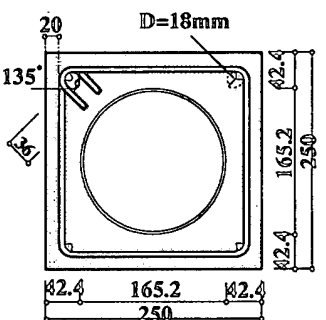

(円形鋼管)
圆 -1 試験体（被覆形）

の中心線で, 板厚 $\mathrm{t}$ の 2.5 倍とした). 円形銅管（板厚 $3.2 \mathrm{~mm}, 2.3 \mathrm{~mm}$, $1.6 \mathrm{~mm}, 1.2 \mathrm{~mm}$ ）は，銅板を円形に加工し，溶接によって製作した. 角形銅管・円形鋼管ともに裹当て金はつけず，完全とけ込み浴接と なるように溶接した. なお,残留応力除去の熱処理は行っていない. C) 配筋 被覆コンクリートの主筋・帯筋はともにD6（SD295）を使 用した，主筋間距離は $194 \mathrm{~mm}$ である。带筋比 ${ }_{\mathrm{w}} \mathrm{p}$ は $1.0 \%$ と $0.5 \%$ と 

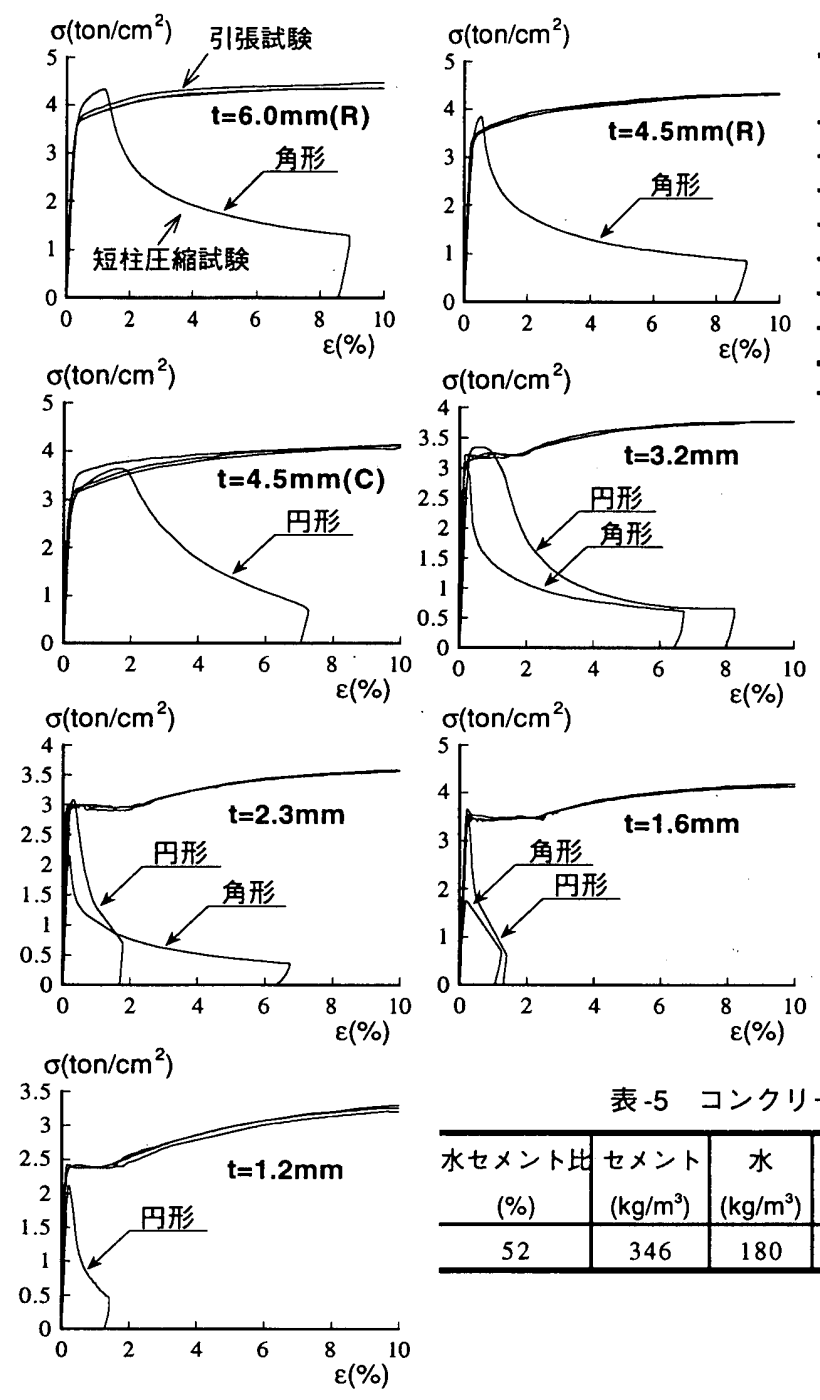

表 -5 コンクリートの調合

\begin{tabular}{|c|c|c|c|c|c|c|}
\hline $\begin{array}{c}\text { 水セメント比 } \\
(\%)\end{array}$ & $\begin{array}{l}\text { セメント } \\
\left(\mathrm{kg} / \mathrm{m}^{3}\right)\end{array}$ & $\begin{array}{c}\text { 水 } \\
\left(\mathrm{kg} / \mathrm{m}^{3}\right)\end{array}$ & \begin{tabular}{|l|} 
細骨材 \\
$\left(\mathrm{kg} / \mathrm{m}^{3}\right)$ \\
\end{tabular} & \begin{tabular}{|l|} 
粗骨材 \\
$\left(\mathrm{kg} / \mathrm{m}^{3}\right)$ \\
\end{tabular} & $\begin{array}{l}\text { 混和剤 } \\
\left(\mathrm{kg} / \mathrm{m}^{3}\right)\end{array}$ & $\begin{array}{l}\text { スランプ } \\
\text { (cm) }\end{array}$ \\
\hline 52 & 346 & 180 & 753 & 1074 & 0.865 & 15 \\
\hline
\end{tabular}

表-3 鋼材の機械的性質

\begin{tabular}{|c|c|c|c|c|c|c|c|}
\hline $\begin{array}{c}\text { 公称板㘣 } \\
(\mathrm{mm})\end{array}$ & $\begin{array}{c}\text { 実測板厚 } \\
(\mathrm{mm})\end{array}$ & 幅厚比 & 径厚比 & $\begin{array}{c}\sigma y\left(\operatorname{ton} / \mathrm{cm}^{2}\right) \\
\mathrm{m} \sigma \mathrm{y}\left(\operatorname{ton} / \mathrm{cm}^{2}\right)\end{array}$ & $\sigma \mathrm{u}\left(\operatorname{ton} / \mathrm{cm}^{2}\right)$ & $\sigma y / \sigma u$ & $\begin{array}{l}\text { 伸ひ } \\
(\%)\end{array}$ \\
\hline 1.2 & 1.21 & - & 138 & 2.39 & 3.45 & 0.739 & 27.3 \\
\hline 1.6 & 1.61 & 94 & 103 & 3.46 & 4.21 & 0.822 & 20.0 \\
\hline 2.3 & 2.19 & 65 & 72 & 2.94 & 3.66 & 0.814 & 21.3 \\
\hline 3.2 & 3.03 & 47. & 51 & 3.20 & 3.78 & 0.847 & 22.2 \\
\hline 4.5 & 4.18 & 33 & - & 3.45 & 4.42 & 0.785 & 28.2 \\
\hline 4.5 & 4.26 & - & 37 & 3.27 & 4.23 & 0.761 & 29.2 \\
\hline 6.0 & 5.62 & 25.0 & - & 3.65 & 4.43 & 0.828 & 24.7 \\
\hline 鉄能D6 & - & - & - & 3.78 & 5.97 & 0.638 & 23.3 \\
\hline
\end{tabular}
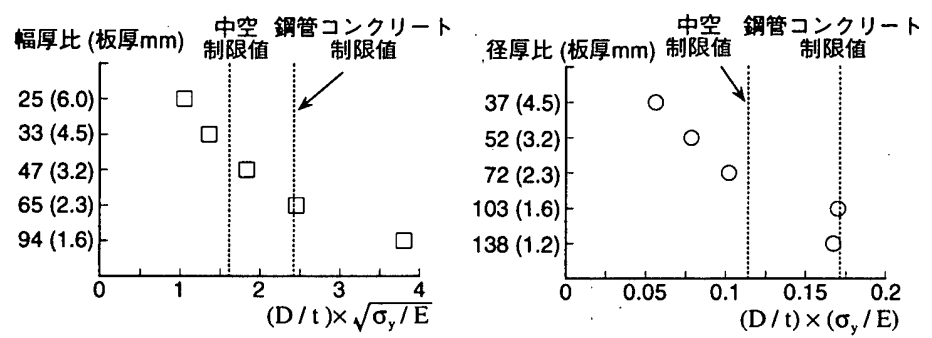

图-3板厚と幅厚比制限值の関係

表-4SRC 規準の幅厚比・径厚比の制限値

\begin{tabular}{c|c|c}
\hline$F$ 值 & 角形 & 円形 \\
\hline$F$ & $\left(74 / F^{0.5}\right) \times 1.5$ & $(240 / F) \times 1.5$ \\
\hline $2.4 \mathrm{t} / \mathrm{cm}^{2}$ & 72 & 150 \\
\hline
\end{tabular}

図-2 忘力度 - Uずみ度関係

し, 間隔は角形鋼管の $\mathrm{wp}=1.0 \%$ で $65 \mathrm{~mm}, 0.5 \%$ で $125 \mathrm{~mm}$, 円形鋼管 の $1.0 \%$ で $75 \mathrm{~mm}, 0.5 \%$ で $150 \mathrm{~mm}$ である。

図-1に試験体の形状・寸法の例として, 被覆形の場合を示す.

d) コンクリートの打設 コンクリートの打設は, 試験体を立て, 上 からコンクリートを落とし込んだ。

e）鋼材の機械的性質，表-3に鋼管および鋼板より切り出したJIS1 号 A 引張試験片による引張試験結果および, 主筋・帯筋に用いた鉄 筋の引張試験の結果を示す. 引張試験は, 既製の角形鋼管・円形銅 管からはそれぞれ 3 本ずつ（鋼管溶接シーム部は含まず）行った. 鋼板は, 加工前の鋼板からそれぞれ 3 本ずつ行った. 表中 $\sigma_{\mathrm{y}, ~} \sigma_{\mathrm{y}}$ は それぞれ鋼管および鉄筋の降伏応力度， $\sigma_{u}$ は引張強度である。

図-2には引張試験と短柱圧縮試験による応力-ひずみ関係を示し ている，短柱圧縮試験は表-2 に示す中空試験体の実験結果である. なお，図中の記号 $\mathrm{t}$ は板厚を示している.

f) 試験体の幅厚比・径厚比と制限值の関係 試験体の幅厚比 - 径 厚比 (板厚) と制限值の関係を図 -3 に示す. 横軸は基準化幅厚比・ 基準化径厚比である（Eは鋼材のヤング係数で $2100 \mathrm{t} / \mathrm{cm}^{2}$ とした）. 図中には, 中空鋼管の幅厚比・径厚比制限値, 鋼管コンクリート構 造の鋼管の幅厚比・径厚比制限値を点線で示している. 中空鋼管の
幅厚比・径厚比制限値は下式で計算した。

$$
\begin{array}{ll}
(D / t) \lim =74 / \sqrt{F} & (\text { 角形鋼管 }) \\
(D / t) \lim =240 / F & (\text { 円形鋼管 })
\end{array}
$$

ここに, D：鋼管の全幅および外径（角形断面の場合の幅厚比の取り 方は規準類によって異なっており，鋼構造設計規準では平板部に対して幅厚 比が規定されているが, 角形鋼管の角部の曲率は製法によって変わるので, 表現の簡単化のため,ここではSRC規準と同様に全幅Dを用いることとし た， $\mathrm{t}$ : 鋼管の板厚, $\mathrm{F}$ : 許容応力度を求めるための基準值（本論文 では引張試験による降伏応力度 $\sigma_{y}\left(\mathrm{t} / \mathrm{cm}^{2}\right)$ を用いた）である，中空 鋼管の基準化幅厚比·径厚比の制限值はそれぞれ $1.61,0.114$ となる. これらの值を1.5倍して, 鋼管コンクリート構造の鋼管の基準化幅厚 比・径厚比の制限值はそれぞれ $2.42,0.171$ となり, 幅厚比・径厚比 制限值は基準值 $\mathrm{F}=2.4 \mathrm{t} / \mathrm{cm}^{2}$ とするとそれぞれ 72 と 150 となる（表-4 参照).

図-3より，裸鉄骨の幅厚比・径厚比制限値に近いのは, 幅厚比で 33,47 , 径厚比で 72 ののであることが分る. 鋼管コンクリートの 幅厚比・径厚比制限值に近いのは幅厚比で 65 , 径厚比で 103,138 の ものであることが分る。

g) コンクリートの調合と圧縮強度 鋼管に充填および被覆するコン クリートの設計強度は $300 \mathrm{~kg} / \mathrm{cm}^{2}$ とし, スランプは $15 \mathrm{~cm}$ を目標とし た（実際はスランプ $14 \mathrm{~cm}$ であった），骨材の最大寸法は $13 \mathrm{~mm}$ であ 
表 -6 耐力の比斡と耐力時のひずみ度

\begin{tabular}{|c|c|c|c|c|c|c|c|}
\hline No. & 試験体 & $\begin{array}{c}\text { 実臨耐力 } \\
\text { Nmax(ton) }\end{array}$ & $\begin{array}{c}\mathrm{Nu} \\
\text { (ton) } \\
\end{array}$ & $\begin{array}{l}\begin{array}{l}N u^{\prime} \\
\text { (ton) }\end{array} \\
\end{array}$ & $\mathrm{Nmax} / \mathrm{Nu}$ & $\overline{\mathrm{Nmax} / \mathrm{Nu}^{\prime}}$ & $\begin{array}{l}\text { 最大耐力時の } \\
\text { ひずみ度 }(\%) \\
\end{array}$ \\
\hline 1 & R25-V & 135.5 & 114.7 & - & 1.18 & - & 1.20 \\
\hline 2 & R25-F & 188.8 & 180.4 & 170.5 & 1.05 & 1.11 & 0.70 \\
\hline 3 & R25-E & 242.0 & 251.4 & 231.1 & 0.96 & 1.05 & 0.62 \\
\hline 4 & R33-V & 90.8 & 81.6 & - & 1.11 & $\cdot$ & 0.54 \\
\hline 5 & R33-F & 154.4 & 149.8 & 139.6 & 1.03 & 1.11 & 0.56 \\
\hline 6 & R33-E & 194.0 & 218.6 & 198.2 & 0.89 & 0.98 & 0.61 \\
\hline 7 & $\mathrm{R} 47-\mathrm{V}$ & 50.4 & 54.5 & - & 0.92 & - & 0.25 \\
\hline 8 & R47-F & 128.4 & 125.0 & 114.4 & 1.03 & 1.12 & 0.45 \\
\hline 9 & R47-E & 181.0 & 192.3 & 171.8 & 0.94 & 1.05 & 0.56 \\
\hline 10 & R47-FE & 273.5 & 261.7 & 230.8 & 1.05 & 1.19 & 0.63 \\
\hline 11 & R65-V & 26.8 & 37.1 & - & 0.72 & - & 0.18 \\
\hline 12 & R65-F & 106.2 & 109.1 & 98.3 & 0.97 & 1.08 & 0.41 \\
\hline 13 & R65-E & 153.8 & 172.5 & 152.3 & 0.89 & 1.01 & 0.42 \\
\hline 14 & R65-EA & 148.0 & 173.0 & 152.7 & 0.86 & 0.97 & 0.46 \\
\hline 15 & R94-V & 15.9 & 31.7 & - & 0.50 & - & 0.18 \\
\hline 16 & R94-F & 99.6 & 104.8 & 93.8 & 0.95 & 1.06 & 0.45 \\
\hline 17 & R94-E & 140.6 & 166.8 & 146.7 & 0.84 & 0.96 & 0.43 \\
\hline 18 & $\mathrm{C} 37-\mathrm{V}$ & 78.5 & 69.4 & - & 1.13 & - & 1.64 \\
\hline 19 & $\mathrm{C} 37 . \mathrm{F}$ & 153.6 & 150.5 & 138.4 & 1.02 & 1.11 & 2.96 \\
\hline 20 & C37-E & 193.0 & 206.6 & 186.2 & 0.93 & 1.04 & 0.46 \\
\hline 21 & $\mathrm{C} 52-\mathrm{V}$ & 51.4 & 49.2 & - & 1.04 & - & 0.64 \\
\hline 22 & $\mathrm{C} 52-\mathrm{F}$ & 128.9 & 132.3 & 119.8 & 0.97 & 1.08 & 1.29 \\
\hline 23 & C52-E & 178.0 & 185.4 & 165.2 & 0.96 & 1.08 & 0.37 \\
\hline 24 & $\mathrm{C} 72-\mathrm{V}$ & 34.4 & 33.2 & - & 1.04 & - & 0.30 \\
\hline 25 & $\mathrm{C} 72-\mathrm{F}$ & 113.2 & 117.6 & 104.9 & 0.96 & 1.08 & 0.74 \\
\hline 26 & C72-E & 153.8 & 170.5 & 150.1 & 0.90 & 1.02 & 0.46 \\
\hline 27 & C72-FE & 245.2 & 237.3 & 206.8 & 1.03 & 1.19 & 0.64 \\
\hline 28 & C103-V & 28.4 & 28.5 & - & 1.00 & - & 0.25 \\
\hline 29 & C103-F & 105.0 & 113.9 & 101.1 & 0.92 & 1.04 & 0.60 \\
\hline 30 & C103-E & 163.4 & 166.6 & 146.1 & 0.98 & 1.12 & 0.48 \\
\hline 31 & C103-EA & 140.2 & 164.7 & 144.4 & 0.85 & 0.97 & 0.46 \\
\hline 32 & C138-V & 13.2 & 15.9 & - & 0.83 & - & 0.22 \\
\hline 33 & C138-F & 90.8 & 101.9 & 89.0 & 0.89 & 1.02 & 0.49 \\
\hline 34 & C138-E & 132.0 & 153.6 & 133.1 & 0.86 & 0.99 & 0.53 \\
\hline
\end{tabular}

表-7 耐力の比較

る.コンクリートの調合表を表-5に示寸.

シリンダー圧縮試験は,断面形の等しい試験体の戴荷期間に1日おき で3本ずつ行った．表-2にコンクリート圧縮強度 $\mathrm{F}_{\mathrm{c}}\left(\mathrm{kg} / \mathrm{cm}^{2}\right)$ を示す.

なお，断面耐力の算定にあたっては，銅管・主筋の降伏応力度 $\sigma_{\mathrm{y}}$, ${ }_{\mathrm{m}} \sigma_{\mathrm{y}}$ は引張試験による值（表-3）を，コンクリート強度 $\mathrm{F}_{\mathrm{c}}$ は, 断面 形の等しい試験体ごとに行ったシリンダー圧縮試験3～6本の平均値 （表一2）を用いた。

\section{3 加力。測定方法}

裁荷は，試験体を $500 \mathrm{t}$ 構造物試験機のベット上に設置し，上下の 加圧板を介して, 中心圧縮加力となるように軸力を単調载荷した. 戴荷時の加力端は上端ピン, 下端回転拘束状態である。試験体材軸 方向の変位測定を, 試験機のベット上にマグネットスタンドによっ て設置した 4 個の変位計を用いて行った。

\section{3. 実験結果と考察}

3. 1 最大耐力

a) 耐力の算定 耐力を下式で算定した.

$N_{u}\left(N_{u}{ }^{\prime}\right)={ }_{s} A \sigma_{y}+{ }_{m} a_{m} \sigma_{y}+{ }_{c} r U c_{c} A F_{c}$

ここで ${ }_{\mathrm{s}} \mathrm{A}$ ：龬管部分の断面積, ${ }_{\mathrm{c}} \mathrm{A} ：$ コンクリート部分の断面積,

\begin{tabular}{|c|c|c|c|}
\hline 断面形式 & 鋼管断面形 & Nmax/Nu & $\mathrm{Nmax} / \mathrm{Nu}^{\circ}$ \\
\hline \multirow[t]{2}{*}{ 中空形 } & 角形 & $0.50 \sim 1.18$ & \\
\hline & 再形 & $0.83 \sim 1.13$ & \\
\hline \multirow[t]{2}{*}{ 充媜形 } & 角形 & $0.95 \sim 1.05$ & $1.06 \sim 1.12$ \\
\hline & 円形 & $0.89 \sim 1.02$ & $1.02 \sim 1.16$ \\
\hline 被覀形 & 角形 & $0.84 \sim 0.96$ & $0.96 \sim 1.05$ \\
\hline$(w p=1.0 \%)$ & 而形 & $0.85 \sim 0.98$ & $0.97 \sim 1.12$ \\
\hline 被唯形 & 角形 & 0.86 & 0.97 \\
\hline$(w p=0.5 \%)$ & 而形 & 0.85 & 0.97 \\
\hline 充填被霞形 & 角形 & 1.05 & 1.19 \\
\hline$(w p=1.0 \%)$ & 而形 & 1.03 & 1.19 \\
\hline
\end{tabular}

$\mathrm{ma}$ : 主筋の全断面積, $\sigma_{\mathrm{y}}$ : 鋼管の降伏応力度, $\mathrm{m} \sigma_{\mathrm{y}}$ : 主筋の降伏応力 度, $\mathrm{F}_{\mathrm{c}}$ : コンクリートの圧縮強度, ${ }_{\mathrm{c}} \mathrm{ru} ： \mathrm{~F}_{\mathrm{c}}$ に対する低隇係数である.

式 (3) 左辺の $\mathrm{N}_{\mathrm{u}}$ と $\mathrm{N}_{\mathrm{u}}{ }^{\prime}$ の違いは, $\mathrm{N}_{\mathrm{u}}$ はコンクリートの強度低減係 数を ${ }_{\mathrm{c}} \mathrm{U}=1, \mathrm{Nu}^{\prime}$ は ${ }_{\mathrm{c}} \mathrm{r}_{\mathrm{U}}=0.85$ としていることである. 以下 $\mathrm{N}_{\mathrm{u}}$ を計算酎 力, $\mathrm{N}_{\mathrm{u}}{ }^{\prime}$ を低減計算耐力と呼ぶ. コンクリート圧縮強度に対する低減 係数は, SRC規準によると被覆鉄筋コンクリートの部分においては， $\mathrm{cru}=0.85-0.6 \mathrm{~s}$ ( $\mathrm{sp}$ ：鋼管比）と定められている.この理由として, 龬 管の存在によりコンクリートの充填度が下がること, 設計式では鋼 管によるコンクリートの断面欠損を考慮に入れていないこと, コン クリートの圧縮ひずみ能力に限界があるため, 累加強度が危険側の 誤差をまねくことが挙げられている.しかし，今回の試験体につい 

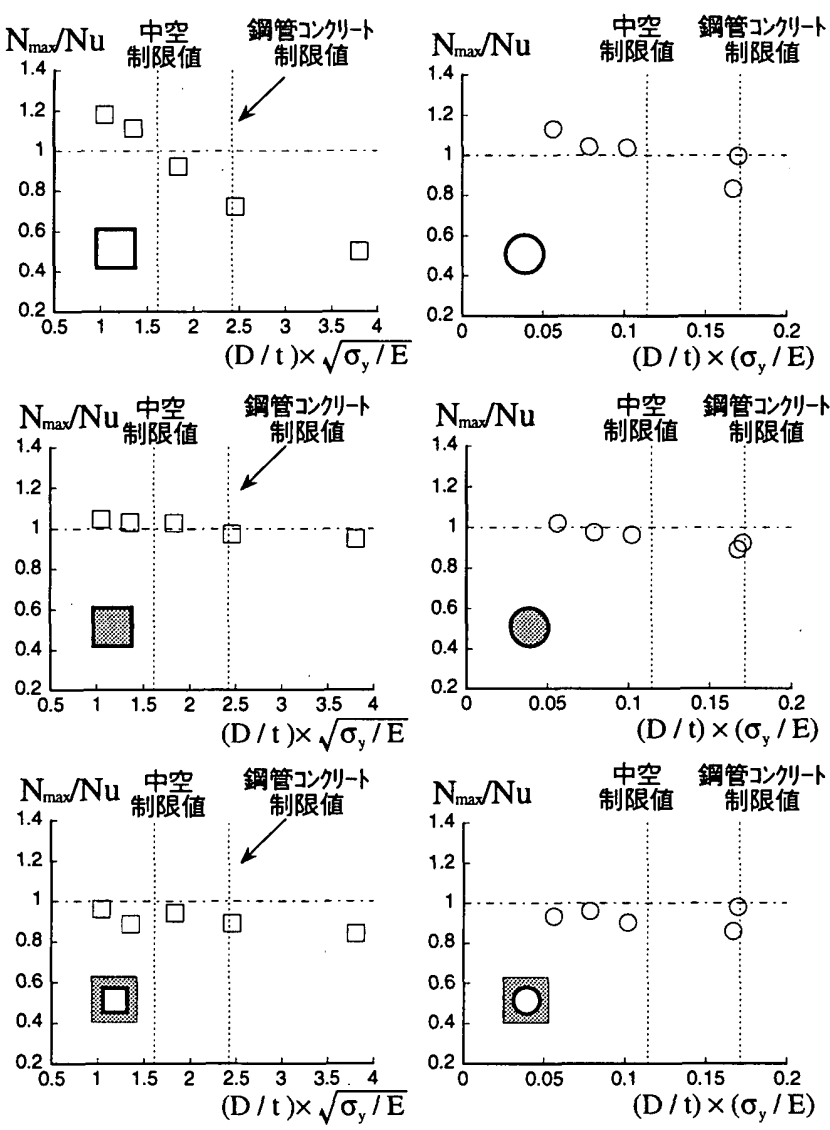

（a）角形鋼管を用いた場合
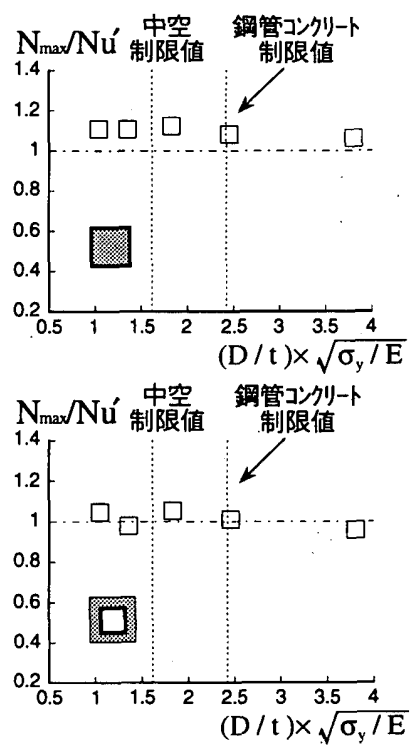

（a）角形鋼管を用いた場合


(b) 円形鋼管を用いた場合

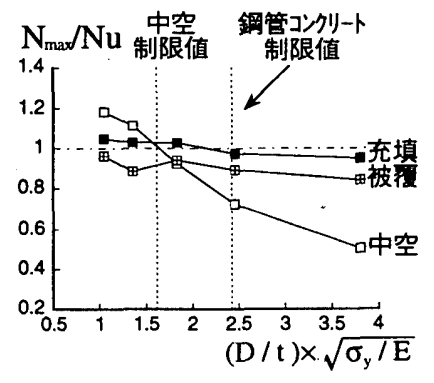

（a）角形鋼管を用いた場合

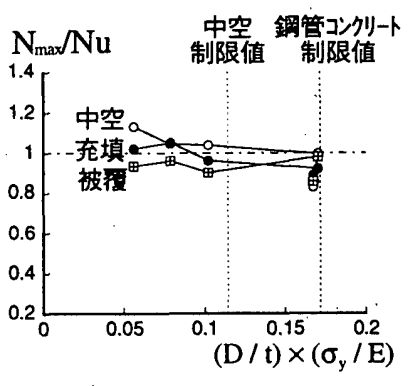

(b) 円形鋼管を用いた場合

ては，製作やコンクリートの打設を丁寧に行ったこと，終局圧縮耐 力の計算において，あらかじめ鋼管によるコンクリートの断面欠損 を考慮していることなどから 0.85 とした。

表 6 に計算酎力 $\mathrm{N}_{\mathrm{u}}$ ，低減計算耐力 $\mathrm{N}_{\mathrm{u}}{ }^{\prime}$ を実験最大耐力 $\mathrm{N}_{\max }$ ととも に示し，また，耐力の比較を示している．表-7に断面形式別に耐力 比をまとめたものを示す。

b) 幅厚比・径厚比の影䇺 図 -4 および 5 にそれぞれ無次元化耐力 $\mathrm{N}_{\max } / \mathrm{N}_{\mathrm{u}}$ ，無次元化低減耐力 $\mathrm{N}_{\max } / \mathrm{N}_{\mathrm{u}}{ }^{\prime}$ と基準化幅厚比・径厚比の関係 を断面形別に示す. 図中点線は中空鋼管の幅厚比・径厚比制限值と その 1.5 倍の值となる SRC 規準が規定する鋼管コンクリート構造で の鋼管の制限值を示している，なお，図中には帯筋比 ${ }_{\mathrm{w}} \mathrm{p}=0.5 \%$ の被 覆形および充填被覆形は示していない。

図 -4より，中空形はその実験耐力 $\mathrm{N}_{\max }$ は角形・円形ともに幅厚 比・径厚比制限值内であれば計算耐力 $\mathrm{N}_{\mathrm{u}}$ を上回っているのが分る.

充填形は計算耐力 $\mathrm{N}_{\mathrm{u}}$ で, 危険側の評価をする場合もあるが, 比較 的精度良く実験酎力を予測している. 低減計算酎力 $\mathrm{N}_{\mathbf{u}}$ 'は幅厚比·径 厚比制限值の1.5倍より小さいものから, 角形においては幅厚比制限 值を越えるものまで安全側に耐力を評価していることがわかる(図5 , 表 -7 参照).

被覆形は計算耐力 $\mathrm{N}_{\mathrm{u}}$ を上回っているものはない.しかし, 低隇計 算耐力 $\mathrm{N}_{\mathrm{u}}{ }^{\prime}$ で現行の SRC 規準の制限値まで，ほほ安全側にかつ精度 良く実験耐力を評価していることがわかる，充填コンクリートに よって鋼管の局部座屈形状が変化し, 幅厚比の大きなものでも計算 酎力 $N_{u}$ が期待できることは知られているが1),5),6)，被覆コンクリー

図-6 断面形式の影響 $(\mathrm{c} r \mathrm{r}=1)$

トによっても同様な効果が期待できることがわかる.

c) 断面形式の影譬 図-6に無次元化耐力 $\mathrm{N}_{\max } / \mathrm{N}_{\mathrm{u}}$ と基準化幅厚比の 関係で断面形式の影響を示している. なお, 帯筋比 $0.5 \%$ の被覆形お よび充填被覆形は示していない.

角形・円形ともに中空形では幅厚比・径厚比が大きくなるにつれ て, 無次元化酎力 $\mathrm{N}_{\max } \mathrm{N}_{\mathrm{u}}$ が小さくなっているのが観察されるが, 充 填形, 被覆形は中空形と比較して, 幅厚比. 径厚比の影響をほとん ど受けていないことが分る.

d) 充填被覆形 表-6より幅厚比 47, 径厚比 72, の中空形・充填形・ 被覆形·充填被覆形の無次元化耐力の比較をすると, 充填被覆形は, 角形鋼管·冈形鋼管どちらの場合もその他の断面形式と比較して最 も酎力が高くなっているのがわかる，これは, 鋼管の局部座屈が充 填コンクリートと被覆コンクリートの両者から拘束されるためであ ると考えられる。

e) 蒂筋比の影響 表-6より, 幅厚比 65 , 径厚比 103 の帯筋比 $1.0 \%$. $0.5 \%$ の比較をすると，角形鋼管・円形鋼管どちらの場合も帯筋比が 小さくなると，酎力が低くなっているのがわかる．これは，带筋に よるコンクリートの拘束力が低下し, コンクリートの圧壊が早く生 じたからだと考えられる。 



（a）角形銅管を用いた場合


$N$ (ton)

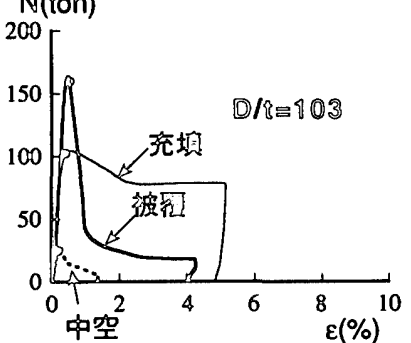

$N$ (ion)

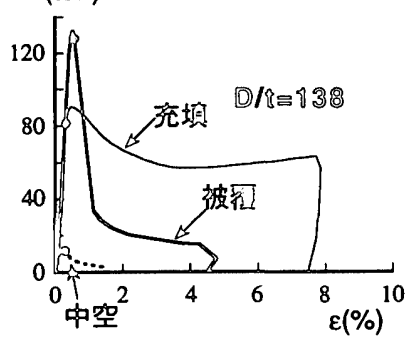



\section{图-7 压缩力ー朝ひずみ閏係}

\section{2 变形性犾}

a) 断面形式の影嘼 図-7は, 幅厚比・径厚比を一定として中空形. 充填形・被覆形 ( $\mathrm{w} \mathrm{p}=1.0 \%$ の場合) の変形性状の比較を示している. 図中の们印は目梘による局部座屈，○印は目視によるコンクリート の圧壊開始点を示している.

図より，被覆形はコンクリート圧壊後に抵抗力が急激に低下し， その後の変形挙動は中空形の線とほほ平行線をたどっているのが観 察される。これは,コンクリートが圧壊した後はコンクリートの耐 力がほほ無くなり，鉦管が主に酎力を受持つからであると推察され る. 充填形は, 中空形·被覆形と比較して最大㓦力以後の抵抗力の

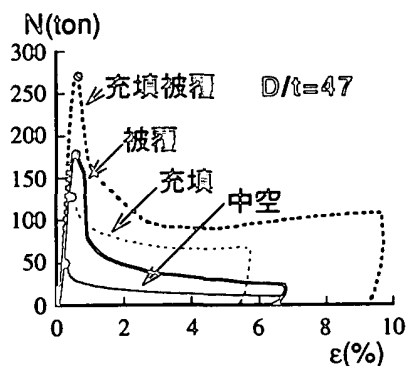

(a) 角形铜管を用いた場合



(b) 円形銅管を椆いた埸合
图-8 充塔被䍂形の誉動

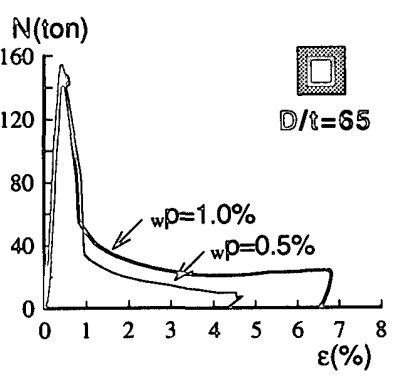

（a）角形䞒管を周いた晹合



(b) 円形鋼管用いた場合
图-9 带筋此の影烸


（a）角形龬管を用いた場合

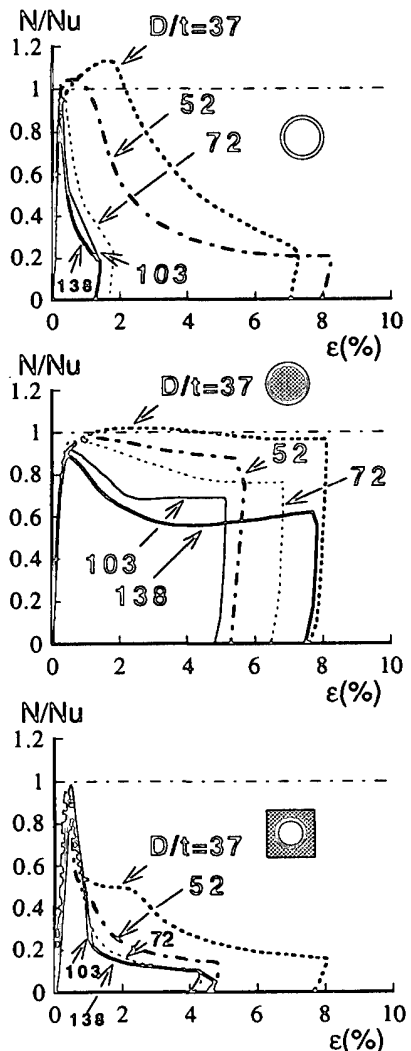

(b) 円形龬管を用いた場合

低下が非常に小さい事がわかる。

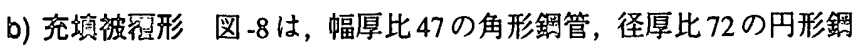
管を用いた充填被覆形の変形性状を同じ幅厚比・径厚比の銅管を用 いた異なった断面形式のものと比較している.

図より,被覆形はコンクリート圧壊後の変形挙動は中空形の線と ほほ平行線をたどっているが, 充填被覆形はコンクリート压壊後の 
変形挙動は充填形の線とほほ平行線をたどっているのが分る。これ は，被覆形と同じようにコンクリート圧壊後は，被覆コンクリート の耐力がほほ無くなり，充填鋼管が主に耐力を受持っているからで あると考えられる。

C) 帯筋比の影響 図-9 は, 幅厚比 65 の角形鋼管, 径厚比 103 の円 形鋼管を用いた帯筋比 $\mathrm{w} \mathrm{p}=1.0 \%$ と $\mathrm{w} \mathrm{p}=0.5 \%$ の被覆形の比較を示して いる. 図より，带筋比が小さい方が，最大耐力は小さく，また耐力 の低下が激しいのが分るが，それほど顕著な差は認められない．

d) 幅厚比・径厚比の影翌 図-10の各図は, 断面形式を一定とし, 幅厚比・径厚比を変化させた場合の圧縮力ーひずみ度関係を示して いる(被覆形の場合は ${ }_{\mathrm{w}} \mathrm{p}=1.0 \%$ ). 縦軸は圧縮力を計算耐力 $\mathrm{N}_{\mathrm{u}}$ で無次 元化している.

図-10より, 中空形は幅厚比・径厚比が大きくなるにつれて, 最 大耐力および最大耐力以後の耐力の低下が大きくなる．充填形は, 幅厚比・径厚比が大きくなるにつれて, 最大酎力以後の耐力の低下 が大きくなるが, 無次元化最大耐力はあまり変わらない. 被覆形む 充填形と同様の傾向が観察されるが, 幅厚比で 65, 94, 径厚比で72, 103，138の挙動はあまり差が認められない.

e) 耐力時のひずみ度 表-6に最大耐力時のひずみ度を示している. 角形銅管では幅厚比 33 以上の充填形, 被覆形, 冈形鋼管では径厚比 72 以上の被覆形, 全ての充填形で中空形よりも最大酎力時のひずみ 度が大きくなっているのが分る. 本論文の実験で中空銅管と最大耐 カのひずみ度が同じ值となるのは, 角形鋼管で幅厚比が 33 , 円形鋼 管で径厚比が52 77となることが観察され，これらの值以上で龬管 の局部座屈に対するコンクリートの拘束の効果が大きくなる.

\section{3 局部座屈形状}

実験後に観察した鋼管の局部座屈形状の特徴を以下に記す。

a) 中空形 角形銅管は，一対の平行する板要素が外側に，もう一対 の板要素が内側に局部座屈した。円形銅管（径厚比 52 を除く）は, エレファントフット形に局部座屈した。径厚比 52 のものは, 外側と 内側に折れ曲がるように局部座屈した。

b) 充填形 角形鋼管も円形鋼管も, 全ての板要素が外側に座屈した。 c) 被覆形 幅厚比 25 以外の角形鋼管は, 全ての板要素が内側に座 屈していた．幅厚比 25 のものは，中空形のものと同じ形状で，一対 の平行する板要素が外側に，もう一対の板要素が内側に局部座屈し た. 円形鋼管は全て内側に座屈していた，板厚が薄くなるほど局部 座屈波の波高が小さかった. 角形・円形ともに鉄筋が座屈した位置 と，鋼管が局部座屈した位置がほほ同じ中央部であった。

被覆形で内側に座屈したのは，被覆コンクリートによって局部座 屈波が外にでるのを拘束されたためだが,中空形と同様の座屈形状 となった幅厚比25の角形鋼管については局部座屈で板要素が外に飛 び出す力がコンクリートの拘束力を上回ったからである考えられる. 被覆形の局部座屈の形状は中空形とは異なっており, 局部座屈荷重 が増大したものと考えられる

d) 充填被覆形 角形鋼管, 円形鋼管ともに充填形と同じく外側に局 部座屈していた。

3. 4 被覆形鋼管コンクリート柱の幅厚比・径厚比の制限値

幅厚比・径厚比の制限值は，1) 降伏応力度までは局部座屈しない こと，2）塑性ヒンジの回転能力を確保すること，3）期待する変形 性能の観点から, 決められている。
本論文での短柱圧縮試験では，上記 2)，3）の観点からの幅厚比 · 径厚比の制限值は決められないが，1）に関連する断面全体としての 酎力の確保という観点からは, SRC 規準の幅厚比・径厚比制限值以 内であれば低隇計算耐力 $N_{\mathbf{u}}$ 'で実験最大耐力を安全側に評価できるこ とから，現行の幅厚比・径厚比制限值は，概ね妥当である.

\section{4. 結論}

現行のSRC規準で規定されている被覆形鋼管コンクリート柱の幅 厚比・径厚比制限値の值が適切かどうかを検討するために, 銅管断 面, 断面形式, 幅厚比・径厚比を主な実験変数に選び, 短柱の圧縮 試験を合計 34 体行った。

実験より得られた知見は以下の通りである。

1) 被覆形は，銅管コンクリート幅厚比・径厚比制限值以内であれば 低減計算酎力 $\mathrm{N}_{\mathrm{u}}{ }^{\prime}$ で実験最大耐力を安全側に評価できる。した がって現行の幅厚比・径厚比制限值は，概ね妥当である。

2) 中空形は，裸鉄骨の幅厚比・径厚比制限値以内であれば計算耐力 $\mathrm{N}_{\mathrm{u}}$ で安全側に評価できることを確認した。

3）充填形は，鋼管コンクリート幅厚比・径厚比制限值以内から制限 値を越えるものまで低隇計算耐力 $\mathrm{N}_{\mathrm{u}}$ で安全側に評価できること 確認した。

今後の課題として，被覆コンクリートの帯筋比の值や鋼管のかぶ り厚さが酎力や変形挙動に及ほす影響を検討することが必要であろ j.さらに, 柱材の変形性能と幅厚比・径厚比の関係が定量化され ることが望まれる。

\section{謝辞}

本実験に際して，九州大学技官，有働文久氏，川口昇氏，久島昭久 氏, 浜辰夫氏，コンクリートの打設に際し，九州大学技官津賀山健 次氏の御協力を得ました。ここに深く感謝致します。

\section{参考文献}

1) 日本建築学会：鉄骨鉄筋コンクリート構造計算规準・同解説, 1987 年 6 月

2) 日本建築学会 : 鋼管コンクリート構造設計規準・同解説，1967. 年 6 月

3）日本建築学会 : 鋼管コンクリート構造計算規準・同解説，1980 年 2 月

4) 日本建築学会 : 鎆構造設計規準, 1973 年

5) 松井千秋: コンクリート立填鋼管構造の構造性能と設計, 銅構造論文集, 第 1 巻第 2 号, pp.11-24, 1994 年 6 月

6) 津田惠吾, 松井千秋: コンクリート充填角形鋼管柱の構造性能と幅厚比制 限值について，鋼構造諭文集，第 1 巻第 2 号, pp.25-36, 1994 年 6 月

7) 若林実, 佐々木良一:鋼管コンクリート構造に関する研究（曲げモーメン 卜を受ける被覆鋼管について)，日本建符学会論文報告集，第 103 号， 1964 年 10 月

8) 牧野桧, 佐藤卓: 鋼管コンクリート構造関する研究（その $2 \cdot$ 曲げ圧箖を 受ける被覆鋼管について), 日本建築学会論文報告集号外, p.334, 1965年 9 月

9）若林実，佐々木良一:鋼管コンクリート構造に関する研究（その $3 \cdot$ せん 断を受ける被覆鋼管について), 日本建築学会論文報告集号外, p.335, 1965 年 9 月

10) 羽會弘人, 高津精一: 鋼管コンクリート構造に関する研究（被覆鋼管の コンクリートかぶり厚さに関する実験)，日本建築学会論文報告集号外， p.337, 1965 年 9 月

11）若林実，南宏一，佐々木良一，小河弘明 : 鋼管コンクリート柱のせん断 強度に関する実験的研究, 京都大学防災研究所年報, 第 21 号 B-1, 1978 年 4 月

（1997年 4 月 30 日原稿受理，1997年 8 月 20 日採用決定） 